\title{
Detection of Leptospira interrogans DNA in Urine of a Captive Ocelot (Leopardus pardalis)
}

\author{
Lucas N. Paz (D), Camila Hamond and Melissa H. Pinna *D
}

check for

updates

Citation: Paz, L.N.; Hamond, C.; Pinna, M.H. Detection of Leptospira interrogans DNA in Urine of a Captive Ocelot (Leopardus pardalis). Int. J. Environ. Res. Public Health 2021, 18, 793. https://doi.org/ 10.3390/ijerph18020793

Received: 9 October 2020

Accepted: 15 January 2021

Published: 19 January 2021

Publisher's Note: MDPI stays neutral with regard to jurisdictional claims in published maps and institutional affiliations.

Copyright: (c) 2021 by the authors. Licensee MDPI, Basel, Switzerland. This article is an open access article distributed under the terms and conditions of the Creative Commons Attribution (CC BY) license (https:// creativecommons.org/licenses/by/ $4.0 /)$.
Bacterial Disease Laboratory (LABAC), School of Veterinary Medicine and Zootechny, Federal University of Bahia, Adhemar de Barros Avenue, 500, Salvador 40170-110, Brazil; lucasnpaz@hotmail.com (L.N.P.); camilahamond@gmail.com (C.H.)

* Correspondence: melissahp@ufba.br; Tel.: +55-(71)-32836749

We read with interest the article recently published by Murillo and collaborators (2020) [1] in The International Journal of Environmental Research and Public Health. The main objective of the study was to evaluate the presence of antibodies against pathogenic Leptospira species and the prevalence of pathogenic Leptospira DNA in the urine and blood in stray cats in Spain. According to the authors, $4.1 \%$ of the animals were seropositive for Leptospira spp. (cutoff = title of 20). One sample $(1.12 \%)$ was positive for the detection of Leptospira DNA. It is noteworthy that this cat did not have antibodies against Leptospira detected by MAT.

Anti-Leptospira antibodies have been described in domestic cats [1-3] and free-living felines worldwide [4-6]. In Brazil, studies with different species of wild felines, free-living or captive, have shown the expose of leptospires in these animals, which vary from $2.5 \%$ to $18.2 \%[4,7,8]$. These studies are notable for characterizing the circulation of Leptospira in a large neotropical felines species from different epidemiological settings. However, in order to characterize chronic carrier animals, it is necessary to investigate the presence of DNA or obtain leptospiral isolates from urine or kidney samples [9].

In recent years, studies have demonstrated the presence of leptospire DNA in the urine and blood of domestic cats [1,3]. Additionally, Alashraf and collaborators (2020) [10] describe, for the first time, the recovery of Leptospira interrogans from urine and kidney samples from naturally infected domestic cats. Such results demonstrate the possibility that domestic cats act as chronic carriers of Leptospira ssp. Studies that characterize wild animals, especially wild felines, as chronic carriers are rare in the literature. Here, we describe for the first time the presence of Leptospira spp. DNA recovered from the urine of a naturally infected captive ocelot (Leopardus pardalis) and without clinical symptoms of leptospirosis. This study was carried out as part of the routine surveillance conducted by the Park's veterinary team.

The microscopic agglutination test (MAT) was performed as recommended by the World Organization for Animal Health [11], using a panel composed of 19 serogroups (Table S1). In MAT, reactivity was observed with the titer of 25 for serovar Canicola. For direct identification of the agent, the amplification was primarily directed towards the detection of the lipL32 gene (present only in pathogenic Leptospira species). Then, the secY housekeeping gene (responsible for determining the Leptospira species) was amplified and the amplicons were purified and sequenced as described by Paz and collaborators (2019) [12]. Genotyping based on the partial secY gene characterized the infecting bacteria as Leptospira interrogans (GenBank accession number MW013523). Phylogenetic analysis was performed with Mega v6 software using the neighbor-joining method. The phylogenetic tree (Figure 1) was built using the Tamura-Nei model [13]. 


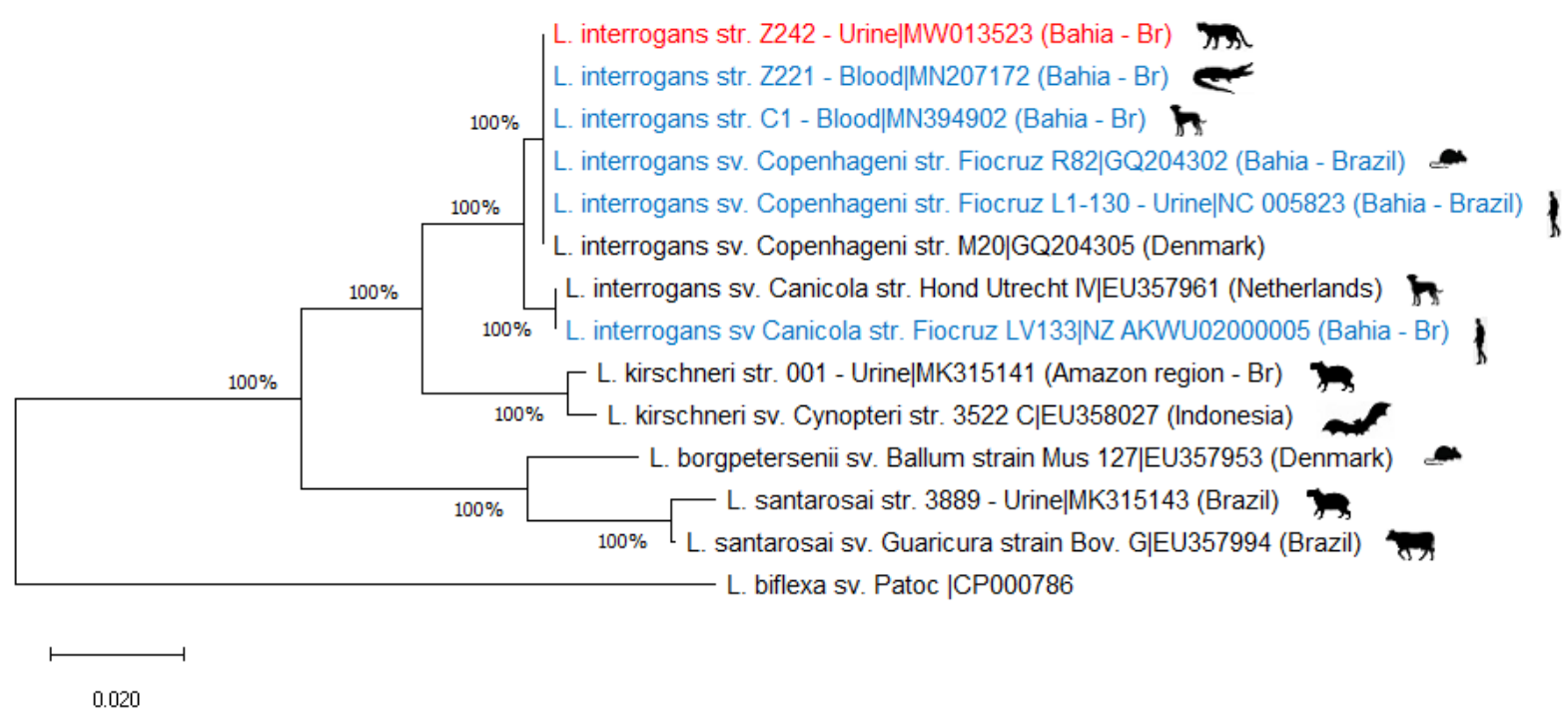

Figure 1. Phylogenetic tree built with secY gene sequence analysis recovered from blood sample of an Ocelot (Leopardus pardalis). Sequence obtained directly from clinical samples (urine) studied in this work are indicated in red, sequences obtained from a L. interrogans strain from, dog, broad-Snouted Caiman, rodents isolated and human, in the same regions are in blue. Additional sequences corresponding to isolates obtained elsewhere from a variety of hosts are indicated in black. After the vertical bar, the GenBank accession number is reported for each sequence. The analysis was made using the maximum-likelihood method (Tamura-Nei model). The support for the branching order was determined by 1000 bootstrap.

We observed that even in the presence of the bacteria, the anti-Leptospira antibody titer was low. These results corroborate with previous studies that demonstrate the presence of DNA [1] or the obtaining of isolates [10] from Leptospira spp. in urine and kidney samples in domestic cats with low or negative MAT titers. Murillo and collaborators (2020) [1] suggest that chronically infected cats can have stable, decreasing or not present antibody titers. In addition, these animals, that do not show antibody titers by MAT, can remain eliminating viable leptospires through urine and serve as a source of infection for other animals and humans.

The identification of wild species as reservoirs of Leptospira brings relevant information about the epidemiology of this pathogen [14]. Domestic cats naturally infected are able to release the pathogenic DNA of leptospira in their urine for up to eight months [15]. Salvador has regions with high rates (37.8 per 1000 individuals per year) of infection for human leptospirosis [16,17]. In addition, pathogenic Leptospira has recently described in surface waters from the urban environment [18]. We infer that these animals may act as chronic carriers of L. interrogans and be a possible source for transmission of the bacteria to other wild and domestic animals or humans, especially for other captive animals and for zoo staff. Although the epidemiological importance of these animals in the leptospirosis transmission chain is not known, our data can assist in the surveillance of leptospirosis, as well as suggest a possible risk to animal and human health and point out new directions for future studies.

Supplementary Materials: The following are available online at https:/ / www.mdpi.com/1660-460 1/18/2/793/s1, Table S1: Leptospiral antigens used on MAT.

Author Contributions: Methodology, L.N.P., C.H. and M.H.P.; formal analysis, L.N.P. and C.H.; data curation, L.N.P. and M.H.P.; writing-original draft preparation, L.N.P.; critical revision of this manuscript C.H. and M.H.P. All authors have read and agreed to the published version of the manuscript.

Funding: This research received no external funding.

Institutional Review Board Statement: Rights: This study was approved by the Research Ethics Committee of the Federal University of Bahia (process 025/09-A) and by the Environmental De- 
partment of Brazil (IBAMA-SIS- BIO) number 38.235-1. All applicable institutional and/or national guidelines for the care and use of animals were followed.

Acknowledgments: The authors would like to thank the Brazilian governmental agencies CAPES (Coordenação de Aperfeiçoamento de Pessoal de Nível Superior) for financial support. LNP received post-graduate scholarships from CAPES (grant: 88882.453699/2019.1).

Conflicts of Interest: The authors declare that the research was conducted in the absence of any commercial or financial relationships that could be construed as a potential conflict of interest.

\section{References}

1. Murillo, A.; Cuenca, R.; Serrano, E.; Marga, G.; Ahmed, A.; Cervantes, S.; Caparrós, C.; Vieitez, V.; Ladina, A.; Pastor, J. Leptospira Detection in Cats in Spain by Serology and Molecular Techniques. Int. J. Environ. Res. Public Health 2020, 17, 1600. [CrossRef] [PubMed]

2. Alashraf, A.R.; Lau, S.F.; Khor, K.H.; Khairani-Bejo, S.; Bahaman, A.R.; Roslan, M.A.; Rahman, M.S.A.; Goh, S.H.; Radzi, R. Serological Detection of Anti-Leptospira Antibodies in Shelter Cats in Malaysia. Top. Companion Anim. Med. 2019, $34,10-13$. [CrossRef] [PubMed]

3. Sprißler, F.; Jongwattanapisan, P.; Luengyosluechakul, S.; Pusoonthornthum, R.; Prapasarakul, N.; Kurilung, A.; Goris, M.; Ahmed, A.; Reese, S.; Bergmann, M.; et al. Leptospira infection and shedding in cats in Thailand. Transbound. Emerg. Dis. 2019, 66, 948-956. [CrossRef] [PubMed]

4. Onuma, S.S.M.; Kantek, D.L.Z.; Crawshaw Júnior, P.G.; Morato, R.G.; May-Júnior, J.A.; de Morais, Z.M.; Ferreira Neto, J.S.; de Aguiar, D.M. Detection of Leptospira spp. and Brucella abortus antibodies in free-living jaguars (Panthera onca) in two protected areas of Northern Pantanal, Brazil. Rev. Inst. Med. Trop. Sao Paulo 2015, 57, 177-180. [CrossRef] [PubMed]

5. Furtado, M.M.; Gennari, S.M.; Ikuta, C.Y.; Jácomo, A.T.d.A.; de Morais, Z.M.; Pena, H.F.d.J.; de Porfírio, G.E.O.; Silveira, L.; Sollmann, R.; de Souza, G.O.; et al. Serosurvey of Smooth Brucella, Leptospira spp. and Toxoplasma gondii in Free-Ranging Jaguars (Panthera onca) and Domestic Animals from Brazil. PLoS ONE 2015, 10, e0143816. [CrossRef] [PubMed]

6. Iatta, R.; Natale, A.; Ravagnan, S.; Mendoza-Roldan, J.; Zatelli, A.; Cavalera, M.A.; Nachum-Biala, Y.; Baneth, G.; Otranto, D. Zoonotic and vector-borne pathogens in tigers from a wildlife safari park, Italy. Int. J. Parasitol. Parasites Wildl. 2020, 12, 1-7. [CrossRef] [PubMed]

7. Ullmann, L.S.; Hoffmann, J.L.; de Moraes, W.; Cubas, Z.S.; dos Santos, L.C.; da Silva, R.C.; Moreira, N.; Guimaraes, A.M.S.; Camossi, L.G.; Langoni, H.; et al. Serologic survey for Leptospira spp. in captive neotropical felids in Foz do Iguaçu, Paraná, Brazil. J. Zoo Wildl. Med. 2012, 43, 223-228. [CrossRef] [PubMed]

8. Lilenbaum, W.; Monteiro, R.V.; Albuquerque, C.E.; Ristow, P.; Fraguas, S.; Cardoso, V.S.; Fedullo, L.P.L. Leptospiral antibodies in wild felines from Rio de Janeiro Zoo, Brazil. Vet. J. 2004, 168, 191-193. [CrossRef]

9. Ellis, W.A. Animal Leptospirosis. In Leptospira and Leptospirosis, Current Topics in Microbiology and Immunology; Adler, B., Ed.; Springer: Berlin/Heidelberg, Germany, 2015; Volume 387, pp. 99-137.

10. Alashraf, A.R.; Lau, S.F.; Khairani-Bejo, S.; Khor, K.H.; Ajat, M.; Radzi, R.; Roslan, M.A.; Rahman, M.S.A. First report of pathogenic Leptospira spp. Isolated from urine and kidneys of naturally infected cats. PLoS ONE 2020, 15, e0230048. [CrossRef] [PubMed]

11. OIE Leptospirosis. Manual of Diagnostic Tests and Vaccines for Terrestrial Animal; OIE: Paris, France, 2018; Volumes 1-3, pp. 503-516. ISBN 78-92-95108-18-9.

12. Paz, L.N.; Hamond, C.; Dias, C.S.; Curvelo, V.P.; Medeiros, M.A.; Oriá, A.P.; Pinna, M.H. Detection of Leptospira spp. in Captive Broad-Snouted Caiman (Caiman latirostris). Ecohealth 2019, 16, 694-700. [CrossRef] [PubMed]

13. Tamura, K.; Stecher, G.; Peterson, D.; Filipski, A.; Kumar, S. MEGA6: Molecular evolutionary genetics analysis version 6.0. Mol. Biol. Evol. 2013, 30, 2725-2729. [CrossRef] [PubMed]

14. Fornazari, F.; Langoni, H.; Marson, P.M.; Nóbrega, D.B.; Teixeira, C.R. Leptospira reservoirs among wildlife in Brazil: Beyond rodents. Acta Trop. 2018, 178, 205-212. [CrossRef] [PubMed]

15. Weis, S.; Rettinger, A.; Bergmann, M.; Llewellyn, J.R.; Pantchev, N.; Straubinger, R.K.; Hartmann, K. Detection of Leptospira DNA in urine and presence of specific antibodies in outdoor cats in Germany. J. Feline Med. Surg. 2016. [CrossRef] [PubMed]

16. Hagan, J.E.; Moraga, P.; Costa, F.; Capian, N.; Ribeiro, G.S.; Wunder, E.A.; Felzemburgh, R.D.M.; Reis, R.B.; Nery, N.; Santana, F.S.; et al. Spatiotemporal Determinants of Urban Leptospirosis Transmission: Four-Year Prospective Cohort Study of Slum Residents in Brazil. PLoS Negl. Trop. Dis. 2016, 10, e0004275. [CrossRef] [PubMed]

17. Felzemburgh, R.D.M.; Ribeiro, G.S.; Costa, F.; Reis, R.B.; Hagan, J.E.; Melendez, A.X.T.O.; Fraga, D.; Santana, F.S.; Mohr, S.; dos Santos, B.L.; et al. Prospective Study of Leptospirosis Transmission in an Urban Slum Community: Role of Poor Environment in Repeated Exposures to the Leptospira Agent. PLoS Negl. Trop. Dis. 2014, 8, e2927. [CrossRef] [PubMed]

18. Casanovas-Massana, A.; Costa, F.; Riediger, I.N.; Cunha, M.; de Oliveira, D.; Mota, D.C.; Sousa, E.; Querino, V.A.; Nery, N.; Reis, M.G.; et al. Spatial and temporal dynamics of pathogenic Leptospira in surface waters from the urban slum environment. Water Res. 2018, 130, 176-184. [CrossRef] [PubMed] 